\title{
Zinc supplements increased growth more in stunted infants than in non-stunted infants
}

Umeta M, West CE, Haidar J, et al. Zinc supplementation and stunted infants in Ethiopia: a randomised controlled trial. Lancet 2000 Jun 10;355:2021-6.

\section{QUESTION: In stunted and non-stunted infants, do zinc supplements promote growth?}

Design

Randomised (unclear allocation concealment*), blinded (investigators and field assistants),* placebo controlled trial with 6 months of follow up.

Setting

Dodota Sire district, central Ethiopia, Africa.

\section{Patients}

100 stunted (length for age $\mathrm{Z}$ score [LAZ] <-2) and 100 non-stunted (LAZ >-2) infants who were 6 to 12 months of age. Inclusion criteria were apparent health and willing participation of mothers. Exclusion criterion was diagnosis of intestinal parasites. 90\% (mean age 10 mo, 53\% boys) of stunted and $94 \%$ (mean age 9 mo, $53 \%$ girls) of non-stunted infants completed the 6 months follow up.

\section{Intervention}

Stunted and non-stunted infants were matched by sex, age, and recumbent length and allocated within the pair to zinc supplement, $10 \mathrm{mg}$ of zinc sulfate in $3 \mathrm{ml}$ of syrup, or placebo syrup. Syrup was given by trained field assistants every morning after the infants were breast fed (but before weaning foods were fed) for 6 days per week for 6 months.

\section{Main outcome measures}

Change in anthropometric measurements: recumbent length (growth), weight, knee-heel length, mid-upper arm circumference, and triceps skinfold.

\section{Main results}

Stunted infants who received zinc supplementation had a 2.5-fold greater increase in growth than stunted infants who received placebo $(\mathrm{p}<0.001)$; the increase in growth in non-stunted zinc supplemented infants did not reach statistical significance (table). Zinc had a greater stimulatory effect in stunted infants than in nonstunted infants $(p<0.001)$. Weight gain did not differ between groups among stunted and non-stunted infants (table). Changes in knee-heel length, mid-upper arm circumference, and triceps skinfold thickness did not reach statistical significance between groups.

\section{Conclusions}

In stunted infants, zinc supplements increased growth.

Source of funding: Nestlé Foundation for the Study of the

Problems of Nutrition in the World.

\section{For correspondence:} Professor C E West, Division of Human

Nutrition and

Epidemiology,

Wageningen University,

PO Box 8129, 6700

EV Wageningen, the

Netherlands. Fax +31

317483342 .
The effect of zinc was greater in stunted than in non-stunted infants.

*See glossary.

\section{COMMENTARY}

The aim of the study by Umeta et al was to investigate whether the low rate of linear growth of apparently healthy breast fed infants in a rural village in Ethiopia can be improved with zinc supplementation.

The results of this high quality study show that daily oral zinc supplementation for 6 months improved the linear growth of stunted infants. The investigators attribute the beneficial effect of zinc to its essential role in the immune system.

The zinc status of the children was assessed using serum and hair, which are acknowledged as imperfect markers of zinc status. None the less, stunted children had lower zinc concentrations than did non-stunted children, and zinc supplementation increased the zinc concentrations of stunted children, further implicating zinc deficiency as a cause of the stunting. Other randomised studies have suggested that zinc supplementation improves the weight gain of malnourished children. ${ }^{1}$

Why are these breast fed infants zinc deficient? The breast milk of malnourished mothers has a zinc concentration similar to that of mothers in developed countries. However, the volume of breast milk produced by malnourished women is lower, and daily zinc intake of their infants at 9 months is as low as $10 \%$ of the recommended daily allowance. 2 This finding is less than the relatively low estimation calculated by Krebs and Hambidge to be essential for growth. We do not know the zinc status of the mothers or the birth weights of the babies, but given the staple diet in Ethiopia, the mothers are likely to be zinc depleted. Zinc deficient mothers have growth retarded babies, ${ }^{4}$ who, in turn, are zinc depleted, increasing the likelihood of zinc deficiency during growth spurts.

The clinical implication of this study is that infants in malnourished communities need more zinc. For breast fed infants, this could be achieved by dietary supplementation of the mothers. ${ }^{5}$ Alternatively, routine supplementation of weaning foods could be implemented and monitored.

Karen Simmer, MBBS, PhD Flinders Medical Centre Bedford Park, South Australia, Australia

1 Simmer K, Khanum S, Carlsson L, et al. Nutritional rehabilitation in Bangladesh-the importance of zinc. Am J Clin Nutr 1988;47:1036-40.

2 Simmer K, Ahmed S, Carlsson L, et al. British milk zinc and copper concentrations in Bangladesh. BrJ Nutr 1990;63:91-6.

3 Krebs NF, Hambidge KM. Zinc requirements and zinc intakes of breast-fed infants. Am J Clin Nutr 1986;43:288-92.

4 Simmer K, Thompson RP. Maternal zinc and intrauterine growth retardation. Clin Sci 1985;68:395-9.

5 Krebs NF, Hambidge KM, Jacobs MA, et al. The effects of a dietary zinc supplement during lactation on longitudinal changes in maternal zinc status and milk zinc concentrations. Am J Clin Nutr 1985;41:560-70.

Zinc supplement $v$ placebo for change in length and weight in stunted and non-stunted infants at 6 months $\dagger$

\begin{tabular}{|c|c|c|c|c|c|c|}
\hline \multirow[b]{2}{*}{ Outcomes at 6 months } & \multicolumn{2}{|c|}{ Stunted } & \multirow{2}{*}{$\begin{array}{l}\text { Difference in means } \\
(95 \% \mathrm{CI})\end{array}$} & \multicolumn{2}{|c|}{ Non-stunted } & \multirow{2}{*}{$\begin{array}{l}\text { Difference in means } \\
\text { (CI) }\end{array}$} \\
\hline & Zinc & Placebo & & Zinc & Placebo & \\
\hline Increase in length $(\mathrm{cm})$ & 7.0 & 2.9 & $4.1(1.4$ to 6.8$)$ & 6.6 & 5.0 & $1.6(-0.8$ to 4.0$) \ddagger$ \\
\hline Increase in weight $(\mathrm{kg})$ & 1.73 & 0.95 & $0.78(-0.32$ to 1.9$) \ddagger$ & 1.19 & 1.02 & $0.17(-0.83$ to 1.17$) \ddagger$ \\
\hline
\end{tabular}

$\dagger \mathrm{Cl}$ defined in glossary and calculated from data in article.

‡Not significant. 